\title{
PENGEMBANGAN MEDIA KARTU “RENSOU KAADO” BERBASIS METODE MNEMONIC UNTUK PEMBELAJARAN KANJI PADA SISWA KELAS XI DAN XII DI SMAN 1 SUKASADA
}

\author{
N. K. M. S. Anggarianti ${ }^{1}$, D. M. S. Mardani ${ }^{2}$, K. E. K. Adnyani ${ }^{3}$ \\ JurusanPendidikanBahasaJepang \\ UniversitasPendidikanGanesha \\ Singaraja, Indonesia \\ e-mail: merianggarianti@yahoo.com \\ desak.mardani@undiksha.ac.id krishna.adnyani@undiksha.ac.id
}

\begin{abstract}
Abstrak
Penelitian ini bertujuan untuk mengembangkan media pembelajaran berupa kartu huruf "Rensou Kaado" berbasis metode mnemonic untuk pembelajaran Kanji pada siswa kelas XI dan XII yang sesuai dengan silabus di SMA N 1 Sukasada. Penelitian ini merupakan penelitian dan pengembangan (research and development.) Metode pengumpulan data yang digunakan dalam penelitian ini adalah (1) observasi, (2) wawancara, dan (3) kuesioner. Hasil penelitian menunjukkan bahwa (1) media pembelajaran yang dihasilkan diberi nama rensou kaado yang berupa kartu huruf bergambar yang memiliki dua sisi yaitu, tampak depan dan belakang. Tampak depan terdapat gambar animasi kartun yang mengasosiasi pada huruf Kanji, goresan serta urutan penulisan huruf Kanji. Tampak belakang kartu berisi gambar pelengkap serta nama kartu,(2) berdasarkan hasil penilaian yang telah dilakukan ke-3 uji ahli tersebut mendapatkan hasil yaitu (1) uji ahli isi mendapatkan hasil sedang, (2) uji ahli media mendapatkan hasil sangat baik, (3)uji ahli respon pengajar mendapatkan hasil sedang, maka media pembelajaran yang dikembangkan sudah baik dan sangat sesuai.
\end{abstract}

Kata Kunci: kartu, rensou kaado,mnemonic, Kanji

要旨

本論文の目的はスカサだ第一公立等学校のシラバスに沿って、ニーモニックの方法で 2 年生および 3 年生にむけた漢字速習用の学習媒体を開発ことである。本論がもちるデータの収集方法は、(1)

観察、(2) インタビュー、(3)

アンケート調查である。本研究結果に基づけた開発された学習媒体連想カードといい、レターカード 形態をしている。表面には漢字の字体を連想される絵がかかれてあり、裏面には事態を補完すると図 ともが書かれている。3人の専門家から得られた結果は、1) 内容の専門家の結果、中級丹もらった2 )メデイアの専門家から高級をもらった、(3)応答の専門家から中級をもらった、次に、開発された学 習媒体は非常に適切である。

カード、連想かーど、ニーモニック、漢字

\section{Pendahuluan}

Bahasa Jepang merupakan bahasa asing yang sekarang ini semakin diminati oleh masyarakat Indonesia. Mulai dari komik, anime, film, drama, lagu, dan budayanya menjadi hal yang membuat masyarakat khususnya kalangan remaja tertarik untuk belajar bahasa Jepang. Bagi orang Indonesia yang mempelajari bahasa Jepang, merupakan bahasa asing yang sulit dipelajari karena memiliki beberapa perbedaan. Diantaranya berbeda dalam hal huruf, kosakata dan juga struktur kalimatnya (Kumalasari, 2011).

Dalam belajar bahasa Jepang huruf sangat penting untuk di pelajari, karena tidak dapat dipelajari secara singkat dan membutuhkan waktu yang cukup lama karena setiap huruf dalam bahasa Jepang memiliki tingkat kesulitan yang berbeda. Belajar huruf Jepang merupakan tantangan tersendiri bagi pebelajar bahasa Jepang disebabkan banyaknya jumlah huruf serta adanya huruf yang hampir sama bentuknya (Mardani, 2012).

Dalam bahasa Jepang terdapat 3 huruf yang harus dipelajari yaitu huruf Hiragana, Katakana, dan Kanji. Dari masing-masing ke 3 huruf di atas memiliki tingkat kesulitan yang cukup sulit. Mulai dari urutan penulisan huruf, goresan yang tepat dan bentuk huruf yang hampir sama (Kumalasari, 2011). Dari ke 3 huruf di atas, masing-masing huruf memiliki 
peranan yang penting, namun di antara ke 3 huruf di atas huruf kanji memiliki peranan yang sangat penting dari ke 3 huruf tersebut dalam mempelajari bahasa Jepang.

Bagi setiap pembelajar bahasa Jepang perlu kiranya mengetahui huruf kanji, kanji merupakan salah satu yang wajib di pelajari, di pahami dan di kuasai, meskipun di sisi lain sering di keluhkan bahwa huruf Kanji merupakan bidang yang sangat sulit di pelajari dalam bahasa Jepang. Bagi masyarakat Indonesia sering di keluhkan bahwa dalam mempelajari bahasa Jepang huruf Kanji sering dianggap sebagai kendala dalam belajar bahasa Jepang. Maka dari itu dalam proses belajar mengajar huruf Kanji perlu adanya sebuah media pembelajaran agar proses belajar mengajar berjalan dengan baik (Khusna, 2015).

Dalam mempelajari huruf Jepangdibutuhkan suatu media pembelajaran yang tepat untuk mempermudah sistem belajar mengajar. Media pembelajaran merupakan sarana fisik untuk menyampaikan isi atau materi pembelajaran contoh, buku, film, video, slide dsb. Dengan demikian dapat dicamkan, media pembelajaran memerlukan peralatan untuk menyajikan pesan dan informasi (Susilana, 2009).

Media pembelajaran yang digunakan harus dapat menarik perhatian siswa pada kegiatan belajar mengajar dan lebih merangsang kegiatan belajar siswa.

Berdasarkan definisi tersebut, media pembelajaran memiliki manfaat yang sangat penting bagi pembelajar agar lebih mudah menyampaikan materi pembelajaran pada siswa. Media pembelajaran yang digunakan harus dapat menarik perhatian siswa pada kegiatan belajar mengajar dan lebih merangsang kegiatan belajar siswa.

Minimnya penggunaan media pembelajaran di sekolah merupakan salah satu kendala dalam mencapai tujuan pembelajaran bahasa Jepang, salah satunya di SMAN 1 Sukasada.Berdasarkan hasil wawancara dengan guru bahasa Jepang di SMAN 1 Sukasada guru jarang menggunakan media untuk mengajarkan siswanya. Hal tersebut dikarenakan sarana dan prasarana untuk mendukung penggunaan media seperti video sangatlah minim. Berdasarkan hasil observasi dan kuesioner didapatkan hasil bahwa siswa masih sulit dalam mengingat ataupun menulis huruf kanji. Hal ini di karenakan siswa kelas XI dan XII masih mengalami kesulitan dalam mengingat huruf kanji dan masih bingung membedakan huruf kanji yang mirip.

Berdasarkan hasil kuesioner mengenai media pembelajaran huruf Kanji, pengajar dan sebagian besar siswa mengatakan penggunaan media pembelajaran berpengaruh terhadap kemampuan dalam mempelajari huruf Kanji. Dikarenakan pentingnya media pembelajaran dalam pembelajaran bahasa asing, maka perlu dikembangkan media pembelajaran yang praktis, menarik, dan mudah untuk digunakan.

Pengajar dan sebagian siswa menginginkan media pembelajaran berupa kartu bergambar mengenai huruf Kanji yang berisi urutan penulisan huruf Kanji lengkap, berwarna, kartu gambar dengan gambar nyata, dan menggunakan gambar animasi kartun dengan menggunakan metode mnemonic agar siswa lebih mudah untuk mengingat huruf Kanji. Penelitian ini merupakan penelitian dan pengembangan (research and development).

Hasil yang di dapat dari penelitian tersebut diberi nama "Rensou Kaādo" yang berupa kartu huruf bergambar yang memiliki dua sisi yaitu, tampak depan dan belakang. Tampak depan terdapat gambar animasi kartun yang mengasosiasi pada huruf Kanji, goresan serta urutan penulisan huruf Kanji. Tampak belakang terdapat gambar animasi kartun dan kosa kata bahasa Jepang. Sedangkan dalam penelitian ini subjek yang diteliti adalah siswa kelas XI dan XII SMAN 1 Sukasada dan objek yang diteliti adalah huruf kanji.

Berdasarkanpaparan tersebut maka tertarik untuk mengembangkan media pembelajaran kartu huruf Kanji bergambar dengan gambar animasi berbasis metode mnemonic sebagai alternatif media pembelajaran untuk mengajarkan huruf Kanji. Dalam kartu ini akan berisi gambar yang terasosiasi kepada bentuk huruf Kanji. Sehingga media yang dikembangkan diharapkan dapat membantu siswa kelas XI dan XII di SMAN 1 Sukasada, dalam menguasai huruf Kanji.

Pada penelitian ini, yang dijadikan sebagai penelitian yang relevan adalah penelitian dari Pertiwi (2015) mengenai dan penelitian dari Primayanti (2014)

\section{Metode}


Dalam penelitian ini menggunakan model penelitian dan pengembangan dari Hannnafin dan Peck. Model Hannafin dan Peck adalah model desain pengajaran yang terdiri dari tiga fase yaitu fase analisis kebutuhan, fase desain, dan fase pengembangan dan implementasi. Hannafin dan Peck Supriatna dkk, (2009) mengatakan dalam model ini, penilaian dan pengulangan perlu dijalankan dalam setiap fase. yaitu:

Model pengembanganperangkatpembelajaranHannafin and Peck terdapat 3 fase,

\section{a) FaseAnalisis}

Fase pertama dari Hannafin dan Peck adalah analisis kebutuhan. Hannafin dan Peck(Supriatna dkk, 2009) menyatakan bahwa fase ini diperlukan untuk mengidentifikasi kebutuhan-kebutuhan dalam mengembangkan suatu media pembelajaran termasuk di dalamnya tujuan dan objektif media pembelajaran yang dibuat, pengetahuan dan kemahiran yang diperlukan oleh kelompok sasaran, peralatan dan keperluan media pembelajaran.

b) FaseDesain

Di dalam fase ini informasi dari fase analisis dipindahkan ke dalam bentuk dokumen yang akan menjadi tujuan pembuatan media pembelajaran. Jumlah kartu yang dirancang sebanyak 50 buah. Desain media kartu "Rensou Kaado" akan digambarkan ke dalam bentuk rancangan kartu yang terdiri dari dua sisi yaitu tampak depan dan tampak belakang yang dapat dilihat pada gambar 3.2 dan 3.3.

c) FasePengembangandanlmplementasi

Hanafin dan Peck (Supriatna dkk, 2009) mengatakan aktivitas yang dilakukan pada fase ini ialah penghasilan diagram alur, pengujian, serta penilaian formatif dan sumatif.Penilaian formatif ialah penilaian yang dijalankan saat proses pengembangan media berlangsung, sedangkan penilaian sumatif dijalankan pada akhir proses.

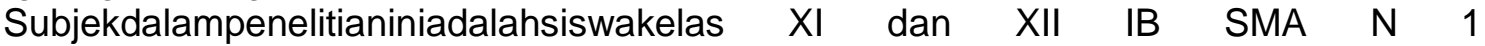
Sukasada.SedangkanobjekdalampenelitianiniadalahhurufKanji.

Metode yang digunakan dalam mengumpulkan data pada penelitian ini adalah metode kuesioner, wawancara dan observasi sedangkan instrumen yang digunakan berupa lembar kuesioner, pedoman wawancara dan lembar observasi.

\section{a. Wawancara}

Wawancaradigunakanuntukmenggaliinformasitentangkendala yang dihadapisiswa, faktorpenyebabsiswamengalamihaltersebut, danhal-hal yang sudahdilakukan guru untukmengatasikendala-kendala yang dihadapisiswadalampembelajaranhurufkanji, sertapemecahanmasalah yang dapatmengatasikendala-kendala yang dihadapisiswa.

b. Angket

Angket digunakan untuk mengetahui kesulitan yang dialami siswa saat mempelajari huruf Kanji.

Angket juga digunakan pada saat proses uji ahli isi bidang studi dan pakar pembelajaran. Angket yang digunakan dalam uji ahli adalah Skala Likert yang disesuaika $n$ dengan pernyataan positif.

Analisis data yang digunakan dalam penelitian ini adalah dengan menggunakan metode kualitatif.Data kualitatif diperoleh dari pemberian angket kepada pengajar bahasa Jepang, siswa, dan pemberian angket kepada ahli isi dan pakar pembelajaran.

\section{Hasil dan Pembahasan}

Penelitian mengenai pengembangan media kartu asosiasi ini telah mencapai hasil yang sesuai. Penelitian dilakukan dengan mengikuti alur dari model penelitian pengembangan oleh Hannafin dan Peck.Adapun pelaksanaan alur Hannafin dan Peck serta hasil dan langkah pembuatan kartu ini akan dijelaskan sebagai berikut.

\section{A. Fase Pertama (Penilaian Kebutuhan)}

Data penilaian kebutuhan didapatkan dari hasil analisis kuesioner yang telah diberikan kepada siswa kelas XI dan XII di SMA Negeri 1 Sukasada yang mendapatkan pelajaran bahasa Jepang. Berdasarkan hasil wawancara, observasi dan kuesioner yang diberikan, didapatkan hasil bahwa dalam proses pembelajaran Kanji di kelas guru sudah menggunakan 
media pembelajaran. Namun media pembelajaran yang digunakan adalah berupa kartu huruf.

Menurut guru yang mengajar bahasa Jepang, media yang telah digunakan dapat menarik minat siswa dalam mempelajari huruf Kanji karena dapat melihat langsung urutan penulisannya dengan jelas. Akan tetapi guru belum pernah mengajarkan huruf Kanji dengan menggunakan kartu bergambar.Pada kartu yang digunakan hanya terdapat huruf saja desain kartu pun sangat sederhana, yakni background berwarna putih dan huruf di bagian tengahnya berwarna hitam. Namun penggunaan media tersebut nampak tidak begituefektif. Maka berdasarkan hasil wawancara, observasi dan kuesioner tersebut penulis bermaksud untuk mengembangkan media kartu bergambar. Bentuk gambar yang dibuat menyerupai dengan huruf Kanji.Selain mempermudah dalam mengingat serta menguasai huruf Kanji, kartu ini juga berisi urutan cara penulisan huruf Kanji, goresan yang tepat serta cara bacanya sehingga dapat membantu siswa dalam belajar huruf Kanji.

B. Fase Kedua (Tahap Desain)

Tahap kedua dari model pengembangan Hannafin dan Peck adalah fase desain. Fase ini merupakan tindak lanjut dari fase sebelumnya, yakni penilaian kebutuhan. Pada fase ini informasi dari fase analisis kebutuhan dipindahkan ke dalam bentuk dokumen yang akan menjadi tujuan pembuatan media pembelajaran.

Dalam penelitian ini media yang dibuat Kartu asosiasi yang berarti "Rensou Kaado". "Rensou kaado" adalah media yang terbuat dari kartu yang berukuran 21 x $29 \mathrm{~cm}$. Dinamakan kartu asosiasi karena di dalam produk ini terdapat gambar yang akan mengasosiasikan ke dalam huruf Kanji. Sehingga siswa akan lebih mudah dalam mempelajari huruf Kanji.

\section{a) Desain Awal Kartu}

Tahap ini diawali dengan pengajuan desain awal kartu, tampilan bagian depan dan bagian belakang kartu, pemilihan warna pada kartu, penyesuaian ukuran tulisan dengan gambar, gambar asosiasi dan gambar urutan penulisan huruf.

Berdasarkan hasil bimbingan diperoleh hasil bahwa ukuran kartu $21 \mathrm{~cm} x 29 \mathrm{~cm}$, gambar akan dibuat secara manual di buku gambar A4 yang kemudian discan dan diwarnai dengan Adobe Photoshop CC 2015. Jumlah gambar disesuaikan dengan jumlah huruf yang dibuat yakni 50 buah gambar untuk asosiasi dengan huruf Kanji dan 1 buah gambar untuk gambar belakang kartu, sehingga total diperlukan 51 buah gambar.

Ukuran tulisan disesuaikan dengan ukuran gambar. Pada bagian depan kartuakan terdapat tiga kolom, yakni tiga kolom di bagian atas dan satu kolom di bagian bawah. Pada kolom bagian atas akan terdapat gambar asosiasi, gambar asosiasi huruf Kanji dan huruf Kanji, goresan serta urutan penulisannya.

Pada kolom bagian bawah akan terdapat penjelasan mengenai asosiasi huruf Kanji dengan gambar. Sedangkan pada bagian belakang kartu hanya penambahan gambar dan nama kartu.

Selanjutnya bagian akhir dari perumusan desain kartu adalah cara penggunaan kartu. Cara penggunaan kartu dibuat untuk memudahkan pengguna kartu (pengajar) dalam menggunakan kartu "Rensou Kaado". Sedangkan pada kolom bagian bawah akan berisi penjelasan tentang asosiasi gambar dan arti dari huruf Kanji. Pada bagian belakang kartu berisi gambar pelengkp serta nama kartu.

b) Cara Pembuatan Kartu

Setelah desain awal kartu dilakukan, langkah selanjutnya adalah pembuatankartu asosiasi yang dilakukan secara mandiri dengan menggunakan aplikasi Adobe Photoshop CC. Langkah pertama yang dilakukan adalah membuat gambar yang akan digunakan di buku gambar A4. Gambar dibuat dengan tangan menggunakan pensil dan kemudian gambarnya di perjelas dengan spidol. Kemudian hasil gambar tersebut discan dan diwarnai menggunakan aplikasi Adobe Photoshop CC.Pembuatan kartu akan menggunakan aplikasi yaitu Adobe Photoshop CC 2015. 
Pembuatan kartu akan menggunakan aplikasi yaitu Adobe Photoshop CC 2015. Pada bagian depan kartu akan terdapat empat kolom, tiga kolom di atas dan satu kolom dibawah. Pada tiga kolom di atas akan diisi dengan gambar

Pemilihan gambar asosiasi yang digunakan pada setiap kartu didasari dengan aspek yang sudah dipelajari oleh siswa. Gambar yang sudah familiar bagi siswa akan mudah dikenali dan juga diingat oleh para siswa. Hal ini juga sejalan dengan buku pelajaran bahasa Jepang Nihon go 1 dan silabus kelas XI dan XII SMA Negeri 1 Sukasada.

\section{Fase Ketiga (Pengembangan dan Implementasi)}

Pada fase ini akan dilakukan validasi atau tinjauan yang dilakukan oleh para ahli, yakni ahli isi atau materi dan ahli media pembelajaran. Hal ini dilakukan untuk mengetahui kelayakanproduk yang dikembangkan. Validasi atau uji ahli akan dilakukan secara terbatas, yakni uji ahli isi atau materi, uji ahli media pembelajaran, dan uji guru atau pengajar.

Produk yang telah didesain sedemikian rupa selanjtnya akan dicetak menjadi kartu gambar yang asli. Kartu yang telah dicetak akan diberikan penilaian oleh para ahli dan juga oleh guru pengajar. Hasil dari penilaian akan digunakan sebagai bahan untuk penyempurnaan produk agar mencapai kualitas yang diinginkan.

\section{PEMBAHASAN}

Penelitian ini dilakukan dengan menggunakan rancangan metode penelitian dan pengembangan R\&D (Research and Development) sesuaidenganmodel pengembangan perangkat pembelajaran Hannafin dan Peck.

Hasil akhir yang didapatkan dan digunakan dalam penelitian ini diperoleh dari hasil observasi langsung di lapangan, penuturan langsung yang diungkapkan oleh pengajar dan juga siswa, kuesioner siswa, dan angket penilaian oleh beberapa uji ahli dan juga pengajar. Observasi dilakukan sebelum revisi saat melaksanakan PPL Real di SMA Negeri 1 Sukasada. Cukup banyak masalah yang ditemukan selama melaksanakan praktek mengajar di sana.

Masalah yang paling umum dialami oleh para siswa yang baru mempelajari bahasa Jepang adalah huruf. Tak sedikit siswa yang tidak hafal huruf Kanji yang digunakan dalam pembelajaran bahasa Jepang. Ada berbagai alasan yang diungkapkan oleh siswa kesulitan dalam menghafal jenis huruf Kanji tersebut.

Ada yang mengatakan bahwa jumlah huruf yang sangat banyak sangat menyulitkan mereka untuk menghafalkannya. Ada pula yang mengatakan bahwa huruf Kanji terlalu banyak goresan sehingga para siswa kesulitan untuk mempelajari baik dari cara baca dan penggunaannya. Hal ini dibuktikan dengan hasil latihan yang selalu dilakukan di setiap akhir pelajaran.

Tidak sedikit siswa yang menulis huruf Kanji yang goresannya secara sembarangan sehingga huruf goresannya pun menjadi tidak beraturan Pengajar bahasa Jepang di SMA Negeri 1 Sukasada juga berpendapat bahwa huruf Kanji jauh lebih sulit dipelajari dibandingkan dari huruf Hiragana dan Katakana. Masalah ini merupakan masalah yang sederhana namun akan memiliki dampak yang cukup besar. Berdasarkan permasalahan tersebut, peneliti memberikan kuesioner kepada beberapa siswa tentang kesan mengenai pembelajaran dan media pembelajaran seperti apa yang diinginkan oleh siswa.

Berdasarkan kuesioner yang diberikan, sebagian besar siswa berpendapat bahwa huruf Kanji merupakan huruf yang sulit dipelajari. Para siswa juga akan mengalami kesulitan jika mempelajari huruf Kanji tanpa bantuan media pembelajaran. Kendala yang dihadapai siswa yakni sulit mengingat cara baca, bentuk, dan urutan penulisan Kanji. Jika para siswa diberikan media pembelajaran berupa kartu, maka kartu yang diinginkan oleh sebagian besar siswa adalah kartu huruf yang dilengkapi kartu gambar dengan gambar animasi, gambar yang berwarna, dan juga dilengkapi urutan penulisan huruf.

Menurut Musfiqon (2012) disebutkan bahwa media berfungsi sebagai sarana yang dapat memberikan pengalaman visual kepada siswa antara lain untuk mendorong motivasi siswa, memperjelas dan mempermudah konsep yang kompleks dan abstrak menjadi lebih sederhana, konkrit serta mudah dipahami. Dengan demikian media dapat berfungsi untuk 
mempertinggi daya serap atau retensi belajar siswa terhadap materi pembelajaran. Selain membangkitkan motivasi dan minat siswa, media pembelajaran juga dapat membantu siswa meningkatkan pemahaman, menyajikan data dengan menarik dan terpercaya, memudahkan penafsiran data, dan memadatkan informasi.

Media haruslah menyenangkan dan menarik. Selain itu media juga harus dapat memberikan pengalaman yang menyenangkan dan juga memenuhi kebutuhan pengguna media itu sendiri. Penggunaan media pembelajaran pada tahap orientasi pembelajaran akan sangat membantu keefektifan proses pembelajaran dan penyampaian pesan dan isi pelajaran. Selain meningkatkan motivasi dan minat belajar, media pembelajaran juga dapat membantu siswa meningkatkan pemahaman, menyajikan data dengan menarik dan terpercaya, memudahkan penafsiran data, dan memadatkan informasi (Arsyad, 2016).

Dalam penelitian ini media yang dibuat diberi nama Kartu Huruf "Rensou Kaado". Rensou kaado adalah media yang terbuat dari kartu yang berukuran $21 \times 29 \mathrm{~cm}$. Pemilihan nama ini dikarenakan kata "Rensou yang berasal dari kata Rensouhou yang berarti asosiasi dan "Kaado" yang berarti kartu. Jadi "Rensō Kādo" berarti Kartu Asosiasi. Dinamakan kartu asosiasi karena di dalam produk ini terdapat gambar yang akan mengasosiasikan ke dalam huruf Kanji. Sehingga siswa akan lebih mudah dalam mempelajari huruf Kanji.

Media kartu yang dibuat ini hanya akan melewati tahap uji ahli dan uji guru/pengajar. Penilaian media ini dilakukan oleh pengajar bahasa Jepang di SMA Negeri 1 Sukasada, seorang ahli isi atau materi, dan seorang ahli media pembelajaran. Pengajar dan para ahli akan diberikan angket penilaian yang akan digunakan untuk menilai produk yang telah dibuat. Angket yang diberikan menggunakan rentang skor 5 , yakni Sangat Sesuai (SS) $=5$, Sesuai $(S)=4$, Kurang Sesuai $(K S)=3$, Tidak Sesuai $(T S)=2$, dan Sangat Tidak Sesuai $(\mathrm{STS})=1$. Dalam angket penilaian juga terdapat kolom kritik dan saran .

Berdasarkan hasil penilaian para ahli dan juga pengajar, media yang dihasilkan sudah bagus, namun masih ada beberapa hal yang harus mengalami perbaikan. Berdasarkan hasil angket penilaian oleh pengajar dan para ahli, diperoleh kesimpulan bahwa media pembelajaran kartu asosiasi huruf Kanji ini mendapat skor 4 dan 5 yang berarti bahwa media pembelajaran ini sudah sesuai dengan tujuan pembuatannya, yaitu membuat media yang unik dan menarik untuk mempermudah siswa mempelajari huruf Kanji.

Pada saat dilakukan uji ahli oleh pengajar, mendapatkan respons yang sangat positif dari pengajar bahasa Jepang di SMA Negeri 1 Sukasada. Berdasarkan wawancara yang dilakukan, pengajar mengungkapkan bahwa media yang dibuat sangat diperlukan oleh beliau sebagai alat bantu dalam mengajar huruf Kanji karena menurut pendapat beliau cukup sulit untuk menemukan kartu asosiasi untuk huruf Kanji.

Beliau juga mengungkapkan bahwa media yang dibuat pasti akan menarik minat siswa untuk belajar huruf Kanji karena media yang dibuat sangat menarik secara tampilan fisik (pemilihan warna dan juga penggunaan gambar). Untuk masing-masing kartu dinilai sangat baik jika digunakan dalam proses pembelajaran.

\section{Simpulan dan Saran}

Simpulan yang dapat dibuat dari penelitian ini adalah media pembelajaran kartu huruf "Rensou Kaado" yang sesuai dengan kebutuhan pengajar di SMA Negeri 1 Sukasada. Media yang diharapkan adalah media yang memuat gambar yang unik dan menarik, gambar dengan warna yang beragam dan nyata. Hal ini dikarenakan para siswa akan jauh lebih tertarik dengan media yang penuh gambar dan juga warna. Selain itu, diharapkan pula pada media ini diselipkan langkah-langkah untuk menulis huruf Kanji agar siswa dapat menuliskan huruf dengan sesuai dan mengikuti aturan penulisan yang benar.

\section{Daftar Pustaka}

Arsyad, Azhar. 2007. Media Pembelajaran. Jakarta : P.T. Raja Grafindo Persada.

Khusna, Muhimmatul. 2015. "Efektivitas Media Visual Bagan Kanji Untuk Meningkatkan Kemampuan Kanji Siswa Kelas XII Bahasa SMA Negeri 12 Semarang. Skripsi.Universitas Negeri Semarang. 
Kumalasari, Novi Deriska. 2011. "Efektivitas Media Lagu Dalam Meningkatkan Pengeuasaan Hiragana Siswa Kelas X SMA Negeri 1 Temanggung". Skripsi. Universitas Negeri Semarang.

Mardani, Desak Made Sri. "Pemanfaatan Media Visual Untuk Meningkatkan Kemampuan Menulis Huruf Hiragana Dan Katakana".Jurnal Pendidikan dan Pengajaran, jilid 45, no 3. Di akses pada tanggal 20 oktober 2016.

Pertiwi, I Gst. Mega Mas Dewi. 2015. " Pengembangan Media Kartu " Rensou kadou"Berbasis Metode Mnemonic Untuk Pembelajaran Hiragana Pada siswa kelas X Di SMAN 1 Sukasada. Skripsi. Universitas Pendidikan Ganesha.

Primayanti, Mega. 2014. "Pengembangan Media Pembelajaran Kartu Pintar Kosakata Bahasa Jepang bagi Kelas Pemula". Jurnal Jurusan Pendidikan Bahasa Jepang, Volume 2, Nomor 1. Di akses pada tanggal 12 september 2016

Supriatna, D dan Mulyadi, M. 2009. Konsep Dasar Desain Pembelajaran. Jakarta : Pusat Pengembangan dan Pemberdayaan Pendidik dan Tenaga Kependidikan RIF.

Susilana, R, \& Riyana, C. 2009. Media Pembelajaran Hakikat, Pengembangan, Pemanfaatan dan Penilaian. Bandung : Jurusan Kurtekped, FIP, UPI. 